\title{
FONOLOGI ISOLEK NON-AUSTRONESIA DI PULAU MOROTAI
}

\section{THE PHONOLOGY OF NON-AUSTRONESIAN ISOLECT IN MOROTAI ISLAND}

\author{
Marwia Hi. Ibrahim \\ Dosen Institut Agama Islam Negeri (IAIN) Ternate \\ Ponsel: 085228842947, Pos-el: Sangapati@gmail.com
}

\begin{abstract}
Abstrak
Penduduk di bagian selatan Pulau Morotai menuturkan isolek yang mirip dengan bahasa Galela, dan sebagian lainnya di bagian utara pulau ini berbahasa Tobelo, di samping itu Desa Pilowo dan Waringin berbahasa Gorap, sebagian kecil lainnya berbahasa Sangir. Penelitian ini bertujuan untuk menjelaskan (1) deskripsi fonologi isolek non-Austronesia di Pulau Morotai. (2) Proses morfofonemik isolek non-Austronesia di Pulau Morotai. Terdapat tiga desa yang dijadikan titik pengamatan, yaitu Desa Daeo di Kecamatan Morotai Selatan, Desa Sangowo dan Desa Mira di Kecamatan Morotai Timur. Setiap titik pengamatan terdiri atas tiga informan. Penjaringan data kebahasaan digunakan Daftar Swadesh. Penyediaan data digunakan metode cakap dan metode simak beserta teknik-tekniknya, seperti teknik cakap semuka, teknik catat dan teknik rekam, juga teknik sadap. Data dianalisis dengan menggunakan metode padan intralingual. Hasil penelitian ini menunjukkan bahwa (1) isolek non-Austronesia di Pulau Morotai memiliki lima bunyi vokal: /a/, /e/, /i/, /o/, dan /u/; 15 bunyi diftong /ia/, /ao/, /uo/, /ou/, /eo/, /ae/, /oi/, /au/, /io/, /oa/, /ue/, /iu/, /ai/, /ui/, dan /ua/; dan 21 bunyi konsonan: /p/, /t/, /k/, /P/, /b/,/dz/, /d/,/g/,/m/, /n/, /n/,/n/,/r/, /f/, $/ \mathrm{s} /, / \mathrm{j} /, / \mathrm{h} /, / \mathrm{g} /, / 1 /, / \mathrm{w} /, / \mathrm{y} /$. (2) Proses morfofonemik pada isolek non-Austronesia di Pulau Morotai terjadi karena adanya proses afiksasi.
\end{abstract}

Kata kunci: fonologi, morfofonemik, isolek non-Austronesia, Pulau Morotai

\section{Abstract}

The people in the southern part of Morotai Island speak a similar isolect with Galela language, and the others in the northern part of the island speak Tobelo language. In addition, the people of Pilowo and Waringin Village speak Gorap language, while the small member of people use Sangir language. This research aims to explain (1) a description of non-Austronesian isolect in Morotai Island. (2) The morphophonemic process of non-Austronesian isolect in Morotai Island. In this research, there are three villages selected as observation points, i.e. Daeo Village in the District of South Morotai, Sangowo and Mira Village in the District of East Morotai. In each point of observation consists of three informants. The elicitation of linguistic data were used Swadesh wordlist. The provision of data were used interview and comprehension methods through face to face interview, note taking, and recording as well as intercepting technique. The data were analyzed by applying intralingual correspondence method. The results of this study suggest that (1) The non-Austronesian isolect in Morotai Island has five vowel sounds: /a/, /e/, /i/, /o/, and /u/; 15 diphtong sounds: /ia/, /ao/, /uo/, /ou/, /eo/, /ael, /oi/, lau/, /io/, /oal, /ue/, /iu/, /ail,

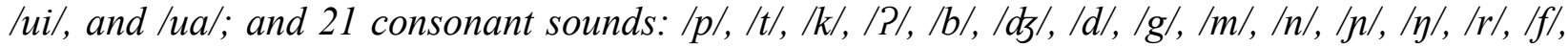

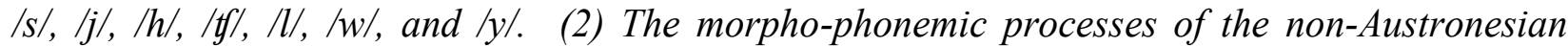
isolect in Morotai Island occur due to affixation process.

Keywords: phonology, morpho-phonemic, non-Austronesia isolect, Morotai Island 


\section{Pendahuluan}

Morotai adalah sebuah pulau yang terdiri dari lima Kecamatan, yaitu Kecamatan Morotai Selatan, Morotai Utara, Morotai Timur, Morotai Selatan Barat dan Morotai Jaya. Kelima Kecamatan ini sebelumnya berada dalam wilayah Kabupaten Halmahera Utara, dan sekarang telah dimekarkan menjadi Kabupaten Morotai.

Masyarakat yang mendiami Pulau Morotai termasuk masyarakat multilingual, di mana mereka menggunakan bahasa Galela, bahasa Tobelo (salah satu bahasa non Austronesia yang ada di Halmahera Utara) dan bahasa Gorap (bahasa Austronesia yang ada di Halmahera Timur) yang dituturkan di Desa Pilowo dan Desa Waringin, berbahasa Ternate dengan intonasi seperti bahasa Tobelo digunakan di Pulau Kolorai, berbahasa Sangir di Pulau Rau dan Darame, dan berbahasa Bugis di Desa Cocomare. Sedangkan bahasa Melayu Pasar digunakan sebagai lingua franca dalam berinteraksi antar penutur yang berlainan bahasa.

Dalam kondisi masyarakat yang multilingual ini, penduduk Morotai tidak menyebut bahasanya dengan "Bahasa Morotai", tetapi tetap menyebutnya bahasa Galela, Tobelo atau Gorap. Namun seperti yang dikemukakan oleh Voorhoeve (1983:17), tidak mungkin jika tidak terdapat perbedaan variasi, apalagi secara geografis Morotai dan Galela adalah dua wilayah yang berjauhan yang dibatasi oleh lautan.

Sebagian besar penduduk di bagian selatan pulau ini menuturkan isolek yang mirip dengan bahasa Galela, dan sebagian lainnya di bagian utara pulau ini berbahasa Tobelo, di samping itu desa Pilowo dan Waringin berbahasa Gorap, sebagian kecil lainnya berbahasa Sangir. Sehari-hari ketika berkomunikasi dengan keluarga atau dengan orang lain mereka berbicara dengan bahasa daerah yang mereka pahami bersama. Jika bukan dari penututr yang sama tetapi masih dari wilyah Maluku Utara mereka akan menggunakan bahasa Melayu Ternate/Halmahera. Sedangkan bila lawan tuturnya di samping dari bahasa yang berbeda tetapi berasal dari luar daerah Maluku Utara, misalnya Jawa dan lain-lain, maka mereka akan berusaha menggunakan bahasa Indonesia sebagai bahasa perantara. Di sekolah atau di kantor-kantor pemerintahan mereka berusaha mengunakan bahasa Indonesia yang benar, namun jika diamati masih terpengaruh bahasa Melayu atau bahasa daerah setempat.

Di desa-desa yang jauh dari kota, selain orang dewasa, anak-anak juga menggunakan bahasa daerahnya, walaupun diselingi dengan kata-kata Melayu/Indonesia, begitu pula sebaliknya, jika ada orang asing yang datang mereka akan berbahasa Melayu/Indonesia, tetapi selalu juga diselingi dengan kosa kata daerahnya. Kita akan kesulitan untuk menemukan orang-orang yang hanya menguasai bahasa daerahnya saja. Orang yang paling tua umurnya pun menguasai bahasa Melayu/Indonesia di samping bahasa daerahnya. Khususnya di Daruba, generasi mudanya jarang yang berbahasa daerah, kebanyakan berbahasa Melayu atau Indonesia. Ada pula kosakata-kosakat tertentu yang sudah tidak digunakan atau juga tidak dipahami oleh mereka, misalnya mereka lebih memahami kata sosakahi 'tempat memasak/dapur'dari pada kata hito 'dapur'.

Keadaan multilingual atau bilingual terjadi di seluruh Maluku Utara, khususnya di pulau Morotai ini. Hal ini terjadi, mungkin karena daerah Maluku Utara berpenduduk multietnis, sehingga setiap orang tidak akan menggunakan bahasa ibunya ketika berhubungan dengan orang dari etnis yang berbeda. Oleh karena itu setiap orang yang ditemui akan menguasai minimal tiga bahasa, yaitu bahasa ibunya, bahasa Melayu sehari-hari dan bahasa Indonesia. Ada juga orang yang menguasai bahasa daerah lainnya seperti bahasa Ternate, Tidore, Makian, atau yang lainnya. Ada pula anak-anak yang tidak menguasai bahasa daerahnya dan hanya menuturkan bahasa Melayu atau Indonesia saja, karena orang tua mereka dari etnis yang berbeda.

Kebanyakan penduduk di Morotai dan Galela pada khususnya dan Maluku Utara umumnya adalah bilingual dan ada yang multilingual, misalnya setiap orang di samping menggunakan bahasa ibunya, dia juga menggunakan bahasa Melayu Maluku Utara 
dengan orang berbeda suku (khusus untuk suku yang berada di Maluku Utara), hal ini dikarenakan banyaknya bahasa daerah di Maluku Utara, dan mereka akan berusaha berbahasa Indonesia yang benar dengan orang dari luar Maluku Utara (misalnya Jawa dll). Hal ini kemudian, terjadi penyerapan kata-kata Melayu ke dalam bahasa daerah, sehingga penuturnya tak lagi tahu bahwa kata tersebut adalah kata serapan, misalnya kata balo 'janda' adalah bahasa Melayu yaitu balu, kobeko 'bengkok', ngamo 'marah' dari kata amok (Wilkoinson, tt: 25, 75 dan 120). Selain itu ada juga kata serapan dari Bahasa Portugis dan Bahasa Belanda, misalnya: mot dari kata moot '(se)potong', bonbon 'permen, panjulus 'pencemburu' dari kata jaloers 'cemburu' (Moeimam dan Steinhauer, 2005; 155, 490 \& 648).

Sementara itu, penutur isolek yang mirip bahasa Galela tesebut, jika ditanyakan mereka orang apa, mereka akan mengatakan bahwa mereka adalah orang Morotai dan mereka tidak mengatakan bahwa mereka adalah orang Galela. Mereka mengidentifikasikan dirinya sesuai daerah tempat tinggal mereka. Isolek yang mirip bahasa Galela ini mesti diperbandingkan dengan bahasa Galela itu sendiri agar dapat diketahui status kebahasaan bagi isolek yang mirip bahasa Galela tersebut.

Kita beralih ke Morotai, di mana penduduknya tidak pernah mengatakan bahasanya adalah bahasa Morotai, padahal jika memperhatikan sejarahnya, Morotai dahulu adalah bagian dari kerajaan Moro, tetapi bahasa penduduknya sekarang bukan bahasa Moro. Belum ditemukan sumber-sumber sejarah yang menjelaskan tentang bahasa Moro, walaupun Portugis sukses di Moro, tetapi belum didapati penjelasan dari sumber Portugis apakah penduduk Moro tersebut berbahasa Moro atau yang lainya. Sekarang ini, Moro lebih dekat dengan hal-hal gaib/mistik bagi penduduk setempat. Ketika memperhatikan kosakata bahasa Moro yang berhasil kami dapatkan dari Bapak Muhammad, ada sedikit kosakata bahasa Moro yang hampir mirip dengan isolek yang mirip bahasa Galela. Sedangkan menurut cerita bapak Muhammad bahwa asal orang-orang
Moro tesebut dari Portugis, tetapi jika bahasa Moro dibandingkan dengan bahasa Portugis, sekilas boleh dikatakan tidak sama, dan apabila dihubungkan dengan pendapat bahwa orang Moro berasal dari Jailolo, maka bahasa Moro yang kami peroleh itupun harus dibandingkan dengan bahasa Sahu/Jailolo. Bapak Muhammad berpendapat bahwa ada bahasa Moro untuk orang Moro yang ada di pulau Morotai, dan ada bahasa Moro "ceme-ceme" yang berhubungan dengan Jailolo, kemungkinan lainnya adalah mungkin saja bahasa Moro merupakan salah satu bahasa non Austronesia dan bahasa yang berbeda dari bahasa daerah lainnya, kesemuanya ini membutuhkan penelitian lebih lanjut.

Penelitian ini tidak akan membahas bahasa Galela, Tobelo, Gorap atau Sangir yang ada di Pulau Morotai. Penelitian ini juga tidak akan membandingkan isolek Morotai dengan bahasa-bahasa yang disebutkan di atas. Penelitian ini hanya terfokus pada deskripsi fonologi isolek Morotai secara sinkronis.

Masalah pokok yang hendak dijawab dalam penelitian yang berkaitan dengan isolek non-Austronesia di Pulau Morotai ini adalah sebagai berikut.

1. Bagaimana deskripsi fonologi isolek nonAustronesia di Pulau Morotai?

2. Bagaimana proses morfofonemik isolek non-Austronesia di Pulau Morotai?

Berkaitan dengan rumusan masalah di atas, penelitian ini bertujuan untuk menjelaskan (1) fonologi isolek nonAustronesia di Pulau Morotai dan (2) proses morfofonemik isolek non-Austronesia di Pulau Morotai.

\section{Teori dan Metode \\ 2.1 Teori}

\subsubsection{Isolek}

Sebelum membahas lebih jauh tentang fonologi isolek non-Austronesia di Pulau Morotai, perlu dijelaskan secara singkat apa itu isolek. Wahya (2011: 1111) menjelaskan bahwa isolek adalah konsep umum sistem bahasa yang tidak membedakan bahasa dan variasinya.

Dari penjelasan singkat ini dapat diketahui bahwa bahasa yang dituturkan di Pulau 
Morotai adalah isolek yang merupakan variasi dari sebuah bahasa.

\subsubsection{Fonologi}

Berdasarkan topik yang diangkat dan memperhatikan rumusan masalah yang telah dikemukakan maka dalam penelitian ini menggunakan teori yang dianggap dapat membantu pemecahan masalah hingga tercapainya tujuan yang diinginkan.

Perbedaan fonologi menyangkut perbedaan fonetik, jadi merupakan perbedaan fonologikal (Mahsun, 1995:23). Fonologi boleh disebut ilmu bunyi yang "fungsional". Misalnya, dalam bahasa Inggris, [t] dan [th] dalam top dan stop kebetulan merupakan bunyi yang "sama" secara "fungsional". Bunyi fungsional kita sebut "fonem". Jadi, [t] dan [th] merupakan dua bentuk yang berbeda dari "fonem" yang sama (alofon). Dasar bukti identitas fonem adalah apa yang dapat kita sebut "fungsi pembeda" sebagai sifat khas fonem itu. Untuk membuktikan bahwa [t] dan [th] merupakan alofon ataukah fonem-fonem yang berbeda, perlulah dicari pasangan minimal dengan perbedaan di antara [th] dan [t] sebagai perbedaan minimal.

Istilah "oposisi" dan "kontras" memainkan peranan penting dalam penelitian fonologis. Oposisi dibedakan sebagai "oposisi langsung" seperti dalam pasangan minimal /1/:/r/ dalam pasangan lupa:rupa dan "oposisi tak langsung" yaitu dua phone yang tidak pernah dapat beroposisi dalam pasangan apapun (minimal atau tidak minimal) padahal kedua phone tersebut jelas berbeda menurut identitas fonemisnya. Pasangan-pasangan kata tertentu menyangkut perbedaan (biasanya minimal) secara fonemis, tidak secara alofonemis, dan "pasangan" tersebut semata-mata merupakan dua bentuk dari satu kata, bentuk yang kebetulan berbeda, secara fonemis.

Pengucapan setiap fonem tergantung dari lingkungan fonem yang bersangkutan dan perbedaan alofonemis tidak mengubah identitas fonem itu sendiri. Akan tetapi, ada juga perubahan pengucapan fonem yang sedemikian rupa sehingga bentuk yang "baru" itu merupakan fonem yang lain. Di samping asimilasi fonemis masih ada berbagai perubahan yang lain yang menyebabkan fonem tertentu menjadi fonem lain, antara lain; modifikasi vokal jenis umlaut, modifikasi vokal jenis ablaut, modifikasi vokal jenis harmoni vokal, netralisasi, hilangnya fonem dan kontraksi, disimilasi, dan metatesis (Verhaar, 2004: 67--93).

\subsubsection{Bunyi Vokal, Diftong, dan Konsonan}

Vokal adalah bunyi bahasa di dalam artikulasi pada (1) bagian yang paling tinggi dari lidah yang ditempatkan bervariasi di dalam suatu zona tertentu di dalam rongga mulut yang bisa digambarkan sebagai area vokal dan (2) tempat keluar arus udara dari paru-paru yang mengeluarkan udara ke tempat terbuka tanpa pertemuan setiap penutupan atau penyempitan sebagaimana akan menyebabkan getaran yang dapat didengar di dalam rongga mulut seperti juga rongga faring. Catatan bahwa kejadian dari getaran yang dapat didengar antara pita suara, yakni suara atau getaran suara, tidak membatalkan bunyi-bunyi vokal dengan syarat disana terjadi pada waktu yang sama tanpa penutupan atau penyempitan di dalam ronggarongga manapun yang tersebut $\mathrm{di}$ atas (Malmkjaer, 1996:24). Jadi, di dalam produksi bunyi bunyi vokal tidak satu pun dari artikulator-artikulator bisa dirapatkan, dan jalan lintasan dari arus udara itu secara relatif tanpa halangan. Bunyi vokal bisa ditetapkan berdasarkan posisi yang paling tinggi dari lidah dan posisi bibir-bibir (Ladefoged, 1982:11). Dengan kata lain perbedaan antara vokal-vokal seperti [a] dan [i], hal itu tegantung dari bangun mulut (Verhaar, 2004:33).

Diftong adalah vokal di dalam artikulasi di mana lidah mulai dengan posisi untuk satu kualitas vokal, dan gerakan-gerakan ke arah posisi untuk vokal yang lain di dalam suku kata nya (lihat: Malmkjaer, 1996:24). Menurut Kridalaksana (2001:43) bahwa diftong adalah bunyi bahasa yang pada waktu pengucapannya ditandai oleh perubahan gerak lidah dan perubahan tamber satu kali, dan yang berfungsi sebagai inti dari suku kata.

Konsonan adalah bunyi bahasa di dalam artikulasi di mana tempat keluar atau masuk arus udara yang manapun mematahkan suatu penutupan atau penyempitan yang boleh atau 
tidak mungkin menyebabkan getaran yang dapat didengar. Konsonan bisa digolongkan menurut cara artikulasi pada suatu pihak dan menurut tempat artikulasi di pihak yang lain. Menurut berbagai cara artikulasi, konsonan digolongkan ke dalam (1) plosive 'bunyi letupan', (2) fricative 'bunyi geseran', (3) affricate 'afrikat', ( 4) approximants 'malaran tak bergeser', (5) nasal 'bunyi sengau', (6) roll 'getar', ( 7) flap 'sentuhan', (8) ejective 'ejektif', (9) implosive 'implosif', dan (10) click 'ceklik'. Penggolongan ini hanyalah salah satu dari mereka yang mungkin berbeda diantara ahli fonetik sekarang (Lihat, Malmkjaer, 1996:26).

\subsubsection{Proses Morfofonemik}

Menurut Ramlan (2001:83) bahwa morfofonemik mempelajari perubahanperubahan fonem yang timbul akibat pertemuan morfem dengan morfem lain. Selanjutnya, Ramlan (ibid) juga mengemukakan bahwa sedikitnya terdapat tiga proses morfofonemik dalam bahasa Indonesia, yaitu proses perubahan fonem, proses penambahan fonem, dan proses hilangnya fonem.

Adapun di dalam Enksilopedia Linguistik dijelaskan bahwa morfofonemik dalam pengertian yang paling luas adalah studi tentang struktur fonologi dari morfem misalnya kombinasi-kombinasi fonem-fonem yang dibolehkan di dalam morfem-morfem dalam setiap bahasa, termasuk variasi fonemik yang morfem-morfemnya mengalami kombinasi satu sama lain, dan studi tentang rangkaian pertukaran atau perubahan berulang di dalam fonem-fonem seperti perubahan dari fonem yang satu ke fonem yang lain (Malmkjaer, 1996:320).

\subsection{Metode}

Penelitian ini menggunakan tiga desa sebagai titik pengamatan, yaitu Desa Daeo di Kecamatan Morotai Selatan, Desa Sangowo dan Desa Mira di Kecamatan Morotai Timur. Dua titik pengamatan di Kecamatan Morotai Timur, dengan alasan karena Desa Mira sebelum terjadi pemekaran wilayah termasuk ke dalam wilayah Kecamatan Morotai Utara.
Setiap titik pengamatan terdiri atas tiga informan.

Penjaringan data kebahasaan dari isolek yang diteliti digunakan Daftar Swadesh dan daftar tanya dengan memperhatikan kosa kata budaya dari isolek yang diteliti yang telah disiapkan. Selanjutnya dalam menjaring data ini didukung dengan kelengkapan teknis lainnya seperti tape recorder, kaset, kertas, pena, tip-ex, pensil, dan lain-lain.

Dalam penyediaan data, penulis menggunakan metode cakap beserta tekniktekniknya. Metode cakap adalah berupa percakapan antara peneliti dengan informan. Adanya "percakapan" antara peneliti dengan informan mengandung arti terdapat kontak antara peneliti dengan informan di setiap daerah pengamatan yang telah ditentukan dalam penelitian tersebut.

Teknik-tekniknya berupa teknik cakap semuka, teknik catat dan teknik rekam. Selain itu, peneliti juga menggunakan Metode simak yaitu untuk memperoleh data dilakukan dengan menyimak penggunaan bahasa. Teknik dasarnya berwujud teknik sadap, dilanjutkan dengan teknik catat dan rekam (Mahsun, 2005: 94-99).

Untuk menganalisis data, penulis menggunakan "Metode Padan Intralingual", yaitu metode analisis dengan cara menghubung-bandingkan unsur-unsur yang bersifat lingual, baik yang terdapat dalam satu bahasa maupun dalam beberapa bahasa yang berbeda (Mahsun, 2005: 112).

Dalam menyajikan hasil analisis penulis menggunakan cara penyajian berupa perumusan dengan menggunakan kata-kata biasa, termasuk penggunaan terminologi yang bersifat teknis, dan juga perumusan dengan menggunakan tanda-tanda atau lambanglambang. (Mahsun, 2005:148).

\section{Hasil dan Pembhasan \\ 3.1 Deskripsi Fonologi \\ 3.1.1 Bunyi vokal}

Isolek Morotai mempunyai lima fonem vokal, yaitu /a/, /e/, /i/, /o/, /u/ seperti pada table berikut. 
Tabel 1

Bunyi Vokal Isolek Morotai

\begin{tabular}{|c|c|c|c|}
\hline & Depan & Pusat & Belakang \\
\hline Tinggi & $\mathrm{i}$ & & $\mathrm{u}$ \\
\hline Tengah & $\mathrm{e}$ & & $\mathrm{o}$ \\
\hline Rendah & & $\mathrm{a}$ & \\
\hline
\end{tabular}

\begin{tabular}{|c|c|}
\hline $\begin{array}{c}\text { Fonem } \\
\text { /a/ }\end{array}$ & $\begin{array}{l}\text { Posisi Awal } \\
\text { [aso] 'panggil' } \\
\text { [ari] 'menangis' } \\
\text { [awa] 'ibu' }\end{array}$ \\
\hline /e/ & $\begin{array}{l}\text { [edze] 'nenek' } \\
\text { [eko] 'atau' } \\
\text { [epe] 'paman' }\end{array}$ \\
\hline /i/ & $\begin{array}{l}\text { [ini] 'gigi' } \\
\text { [ino] 'makanan' } \\
\text { [ija] 'beli' }\end{array}$ \\
\hline /o/ & $\begin{array}{l}\text { [oko] 'berdiri' } \\
\text { [oho] 'hidup' } \\
\text { [odzo] 'makan' }\end{array}$ \\
\hline$/ \mathrm{u} /$ & $\begin{array}{l}\text { [uhi] 'alir' } \\
\text { [uga] 'tebu' } \\
\text { [uto] 'paru-paru' }\end{array}$ \\
\hline
\end{tabular}

Pada Tabel 1 telah terlihat kelima bunyi vokal tersebut terdistribusi secara merata pada posisi awal, tengah dan akhir kata.

Fonem-fonem vokal dalam isolek Morotai terdistribusi secara merata pada posisi awal, tengah, dan akhir kata seperti pada contohcontoh berikut ini.

$\begin{array}{ll}\begin{array}{l}\text { Posisi Tengah } \\ \text { [lake] 'daging' }\end{array} & \begin{array}{l}\text { Posisi Akhir } \\ \text { [soka] 'daun' }\end{array} \\ \text { [kapo] 'debu' } & \text { [yona] 'kamu' } \\ \text { [tame] 'duduk' } & \text { [muna] 'dia (pr)' } \\ \text { [teho] 'peras' } & \text { [ladze] 'lidah' } \\ \text { [pego] 'ekor' } & \text { [saane] 'tiga' } \\ \text { [kanena] 'di sini' } & \text { [take] 'jitak' } \\ \text { [kiliho] 'balik' } & \text { [tagi] 'berjalan' } \\ \text { [gisisi] 'benih padi' } & \text { [gasi] 'buruk' } \\ \text { [hike] 'beri' } & \text { [kulubati] 'cacing' } \\ \text { [motoha] 'lima' } & \text { [neko] 'jalan' } \\ \text { [bolowo] 'lurus' } & \text { [lako] 'mata' } \\ \text { [yoha] 'lebar' } & \text { [poko] 'perut } \\ \text { [wuwu] 'tiup' } & \text { [nanaru] 'rumput' } \\ \text { [nuna] 'muntah' } & \text { [nunu] 'hidung' } \\ \text { [pupuku] 'lutut' } & \text { [dzohu] 'kaki' }\end{array}$

Pencarian fonem-fonem vokal tersebut dilakukan dengan mencari pasangan minimal. Pasangan minimal fonem-fonem vokal isolek

/i/ :/e/
le/ :/a/
/a/ :/o/
/a/ :/u/
/o/ :/e/
/o/ :/u/
/u/ :/e/
/i/ :/u/
/i/ : /a/
/ii/ : /o/

[ari] 'menangis' :

[ori] 'penyu' :

[siri] 'sakit' :

[dzohe] 'tawa' :

[yone] 'kita'

[rube] 'buyung'

[goga] 'demam' :

[dota] 'antar' :

[baro] 'kain'

[yuna] 'muntah' :

[dzoha] 'biar'

[iha] 'empat'

[lako] 'mata'

[gogo] 'bulu'

[tamo] 'beras'

[tupo] 'tuba'

[lagu] 'jarang'

[sahu] 'panas'

[ḑohu] 'kaki'

[osi] 'mandi'

[igi] 'bubu'

[yohi] 'saya'

[yomi] 'kami'

[soki] 'bakau'

[rihi] 'diam'

[igi] 'bubu'

[rika] 'tungku'
Morotai yang ditemukan sebagaimana yang dikemukakan berikut ini.

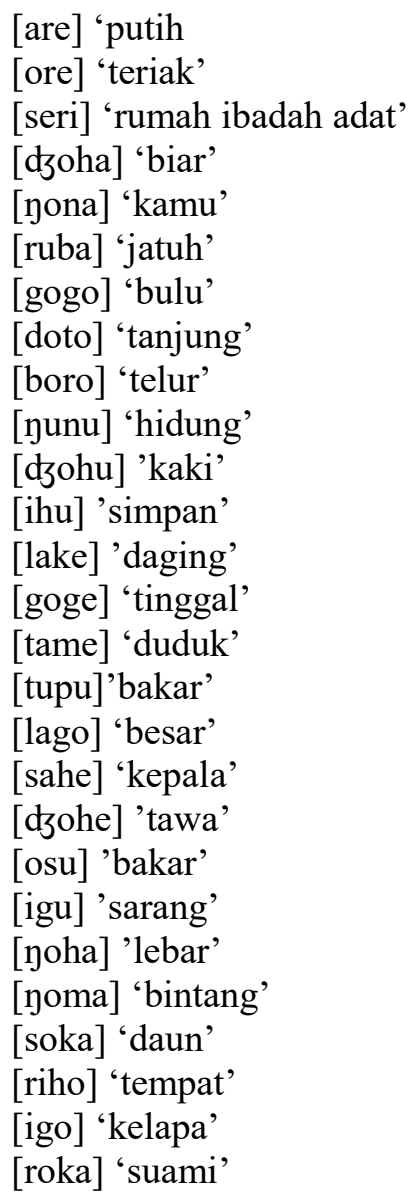




\subsubsection{Bunyi diftong}

Diftong adalah vokal di dalam artikulasi di mana lidah mulai dengan posisi untuk satu kualitas vokal, dan gerakan-gerakan ke arah posisi untuk vokal yang lain di dalam suku kata nya (lihat: Malmkjaer, 1996:24). Menurut Kridalaksana (2001:43) bahwa diftong adalah bunyi bahasa yang pada waktu pengucapannya ditandai oleh perubahan gerak lidah dan perubahan tamber satu kali, dan yang berfungsi sebagai inti dari suku kata. Isolek Morotai memiliki 15 diftong seperti pada contohcontoh berikut ini.

\section{Tabel 2}

Bunyi Diftong Isolek Morotai

\begin{tabular}{|c|c|c|c|}
\hline Fonem & $\begin{array}{l}\text { Posisi } \\
\text { Awal }\end{array}$ & $\begin{array}{l}\text { Posisi } \\
\text { Tengah }\end{array}$ & $\begin{array}{l}\text { Posisi } \\
\text { Akhir }\end{array}$ \\
\hline \multirow[t]{4}{*}{ /ia/ } & & $\begin{array}{l}\text { [kiaro] } \\
\text { 'bakul' }\end{array}$ & [kia] 'apa' \\
\hline & & $\begin{array}{l}\text { [galiasa] } \\
\text { 'lengkua } \\
\text { s' }\end{array}$ & $\begin{array}{l}\text { [gia] } \\
\text { 'tangan' }\end{array}$ \\
\hline & & $\begin{array}{l}\text { [pariama } \\
\text { ]'bintang } \\
\text { tujuh' }\end{array}$ & $\begin{array}{l}\text { [ria] } \\
\text { 'kakak' }\end{array}$ \\
\hline & & & $\begin{array}{l}\text { [sia-sia] } \\
\text { 'timba' }\end{array}$ \\
\hline \multirow[t]{2}{*}{ /ao/ } & & & \begin{tabular}{|l|} 
[bao] \\
'apung'
\end{tabular} \\
\hline & & & $\begin{array}{l}\text { [galao] } \\
\text { 'petung, }\end{array}$ \\
\hline \multirow[t]{2}{*}{ /uo/ } & & & $\begin{array}{l}\text { [muruo] } \\
\text { 'beberapa' }\end{array}$ \\
\hline & & & $\begin{array}{l}\text { [puo] } \\
\text { 'lahir' }\end{array}$ \\
\hline \multirow[t]{3}{*}{$/ \mathrm{ou} /$} & & & $\begin{array}{l}\text { [torou] } \\
\text { 'buruk' }\end{array}$ \\
\hline & & & $\begin{array}{l}\text { [lou] } \\
\text { 'bambu' }\end{array}$ \\
\hline & & & $\begin{array}{l}\text { [mou] } \\
\text { 'bisu' }\end{array}$ \\
\hline \multirow[t]{2}{*}{ /eo/ } & & & [deo] 'dan' \\
\hline & & & [teo] 'laut' \\
\hline \multirow[t]{3}{*}{ /ae/ } & & & $\begin{array}{l}\text { [pu'ae] } \\
\text { 'gali' }\end{array}$ \\
\hline & & & $\begin{array}{l}\text { [magae] } \\
\text { 'rajin' }\end{array}$ \\
\hline & & & $\begin{array}{l}\text { [lae] } \\
\text { 'benang' }\end{array}$ \\
\hline \multirow[t]{2}{*}{ /oi/ } & & & $\begin{array}{l}\text { [paramoi] } \\
\text { 'lain' }\end{array}$ \\
\hline & & & $\begin{array}{l}\text { [doi] } \\
\text { 'pinggang' }\end{array}$ \\
\hline
\end{tabular}

\begin{tabular}{|c|c|c|c|}
\hline & & & [moi] 'satu' \\
\hline \multirow[t]{3}{*}{$/ \mathrm{au} /$} & $\begin{array}{l}\text { [aulot } \\
\text { o] } \\
\text { 'perin } \\
\mathrm{g}\end{array}$ & & $\begin{array}{l}\text { [nau] } \\
\text { 'lelaki' }\end{array}$ \\
\hline & & & [tau] 'tarik' \\
\hline & & & $\begin{array}{l}\text { [hau] } \\
\text { 'pancing' }\end{array}$ \\
\hline \multirow[t]{3}{*}{ /io/ } & & & $\begin{array}{l}\text { [tihio] } \\
\text { 'sempit' }\end{array}$ \\
\hline & & & $\begin{array}{l}\text { [rio] } \\
\text { 'menolong' }\end{array}$ \\
\hline & & & $\begin{array}{l}\text { [bio] } \\
\text { 'wajah' }\end{array}$ \\
\hline \multirow[t]{3}{*}{ /oa/ } & & & $\begin{array}{l}\text { [toa]'meno } \\
\text { njol } \\
\text { keluar' }\end{array}$ \\
\hline & & & $\begin{array}{l}{[\text { toroa] }} \\
\text { 'mertua' }\end{array}$ \\
\hline & & & $\begin{array}{l}{[\text { boa] }} \\
\text { 'nanah' }\end{array}$ \\
\hline /ue/ & & $\begin{array}{l}\text { [tutuene] } \\
\text { 'tumit' }\end{array}$ & $\begin{array}{l}\text { [lue] } \\
\text { 'ombak' }\end{array}$ \\
\hline \multirow[t]{2}{*}{ /iu/ } & & & $\begin{array}{l}\text { [ciu- } \\
\text { ciu]'anakny } \\
\text { a cucu' }\end{array}$ \\
\hline & & & $\begin{array}{l}{[\mathrm{siu}] \text { 'jala }} \\
\text { kecil' }\end{array}$ \\
\hline \multirow[t]{3}{*}{ /ai/ } & & $\begin{array}{l}\text { [yaiti] } \\
\text { 'jarum }\end{array}$ & $\begin{array}{l}\text { [bobai] } \\
\text { 'bertunanga } \\
\text { n' }\end{array}$ \\
\hline & & $\begin{array}{l}\text { [galaiti] } \\
\text { 'tombak }\end{array}$ & $\begin{array}{l}{[\text { kai] }} \\
\text { 'kawin' }\end{array}$ \\
\hline & & $\begin{array}{l}\text { [kailupa] } \\
\text { 'kapuk' }\end{array}$ & $\begin{array}{l}\text { [dodai] } \\
\text { 'piring' }\end{array}$ \\
\hline \multirow[t]{2}{*}{ /ui/ } & & & $\begin{array}{l}\text { [gugui] } \\
\text { 'gayung, }\end{array}$ \\
\hline & & $\begin{array}{l}\text { [tutuili] } \\
\text { "pipit' }\end{array}$ & $\begin{array}{l}\text { [guui] } \\
\text { 'ringan' }\end{array}$ \\
\hline \multirow[t]{2}{*}{ /ua/ } & & $\begin{array}{l}\text { [tuada] } \\
\text { 'nangka' }\end{array}$ & $\begin{array}{l}\text { [halua] } \\
\text { 'noga' }\end{array}$ \\
\hline & & & $\begin{array}{l}\text { [borua] } \\
\text { 'peti' }\end{array}$ \\
\hline
\end{tabular}

\subsubsection{Bunyi Konsonan}

Konsonan adalah bunyi bahasa di dalam artikulasi di mana tempat keluar atau masuk arus udara yang manapun mematahkan suatu penutupan atau penyempitan yang boleh atau tidak mungkin menyebabkan getaran yang dapat didengar. Isolek Morotai memiliki 21 fonem konsonan dan dapat dilihat pada tabel di bawah 
Tabel 3

Bunyi Konsonan Isolek Morotai

\begin{tabular}{|c|c|c|c|c|c|c|c|c|}
\hline & & bilabial & labiodental & dental & alveolar & palatal & velar & glottal \\
\hline \multirow{2}{*}{ letupan } & $\mathrm{tb}$ & $\mathrm{p}$ & & & $\mathrm{t}$ & & $\mathrm{k}$ & $?$ \\
\hline & $\mathrm{b}$ & $\mathrm{b}$ & & $d_{3}$ & $\mathrm{~d}$ & & $\mathrm{~g}$ & \\
\hline \multirow{2}{*}{ nasal } & tb & & & & & & & \\
\hline & $\mathrm{b}$ & $\mathrm{m}$ & & & $\mathrm{n}$ & $\mathrm{n}$ & $\mathrm{y}$ & \\
\hline \multirow[t]{2}{*}{ getar } & $\mathrm{tb}$ & & & & & & & \\
\hline & $\mathrm{b}$ & & & & $\mathrm{r}$ & & & \\
\hline \multirow[t]{2}{*}{ frikatif } & $\mathrm{tb}$ & & $\mathrm{f}$ & & $\mathrm{S}$ & $\mathrm{j}$ & & $\mathrm{h}$ \\
\hline & $\mathrm{b}$ & & & & & t5 & & \\
\hline \multirow[t]{2}{*}{ lateral } & tb & & & & & & & \\
\hline & $\mathrm{b}$ & & & & 1 & & & \\
\hline \multirow[t]{2}{*}{ semi vokal } & $\mathrm{tb}$ & & & & & & & \\
\hline & $\mathrm{b}$ & $\mathrm{W}$ & & & & $\mathrm{y}$ & & \\
\hline
\end{tabular}

*keterangan: tb adalah 'tak bersuara'; b adalah 'bersuara'

Distribusi konsonan dalam isolek Morotai sebagian besar terdapat pada posisi awal atau tengah kata, karena kata-kata dalam Isolek Morotai pada umumnya kata-katanya terdiri atas suku kata terbuka. Namun demikian, ada beberapa kata yang berakhir dengan suku kata tertutup dan jumlahnya sangat sedikit. Hal ini terjadi karena penghilangan vokal pada posisi

\section{Fonem Posisi Awal}

$/ \mathrm{p} / \quad$ [paro] 'angin'

[pesa] 'basah'

[pego] 'ekor'

/b/ [bao] 'apung'

[bulutu] 'balik'

[bolowo] 'lurus'

/dz/ [dzopo] 'asap'

[djobo] 'bengkak'

[dziha] 'buru (ber)'

/t/ [tupu] 'bakar'

[tero] 'benar'

[tibo] 'berenang'

/d/ [dala] 'banyak'

[dudu] 'kering'

[dipa] 'langit'

/k/ [kaso] 'anjing'

[kiliho] 'balik'

[kapo] 'debu'

/g/ [gisisi] 'benih padi'

[gogo] 'bulu'

[gasi] 'buruk'

$/ \mathrm{m} /$ [moane] 'baru'

[muruo] 'beberapa'

[mela] 'busuk'

/n/ [nao] 'ikan'

[nako] 'kalau'

[nau] 'laki-laki'

/n/ [nimo] 'tali pancing'

\section{Posisi Tengah}

[dzipo] 'hantam'

[pipi] 'hisap'

[gitipi] 'kuku'

[tubuso] 'berat'

[maraba ka] 'di dalam'

[gubali] 'kiri'

[odzo] 'makan'

[pedzeka] 'isteri'

[kidsipo] 'kelahi (ber)'

[teto] 'batu'

[leta] 'belah'

[eto] 'hitung'

[tiodo] 'cuci'

[udo] 'minum'

[yodu] 'semua'

[ake] 'air'

[uku] 'api'

[lake] 'daging'

[tagi] 'pergi'

[lago] 'besar

[goge] 'tinggal'

[tooma] 'bunuh'

[namo] 'burung'

[tame] 'duduk'

[sinoto] 'dua'

[yunu] 'hidung'

[una] 'dia (lk)' akhir kata dan sebagian lainnya adalah katakata serapan yang mana tidak terjadi penghilangan konsonan pada posisi akhir kata ataupun tidak terjadi penambahan vokal pada posisi akhir dari kata serapan tersebut. Berikut ni adalah fonem-fonem konsonan Isolek Morotai berdasarkan distribusinya.

\section{Posisi Akhir}

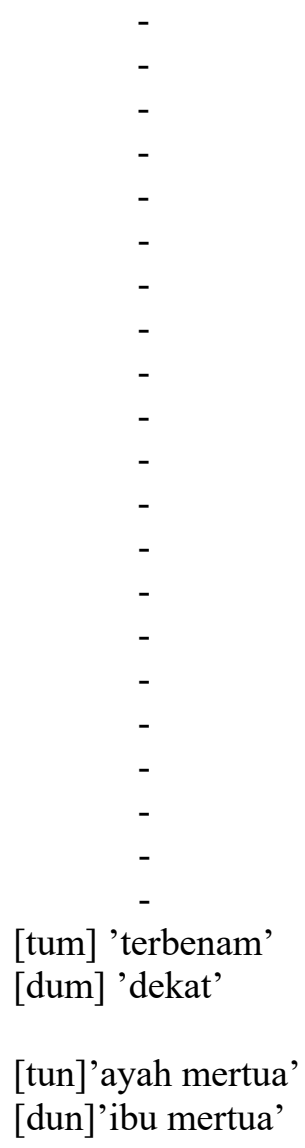




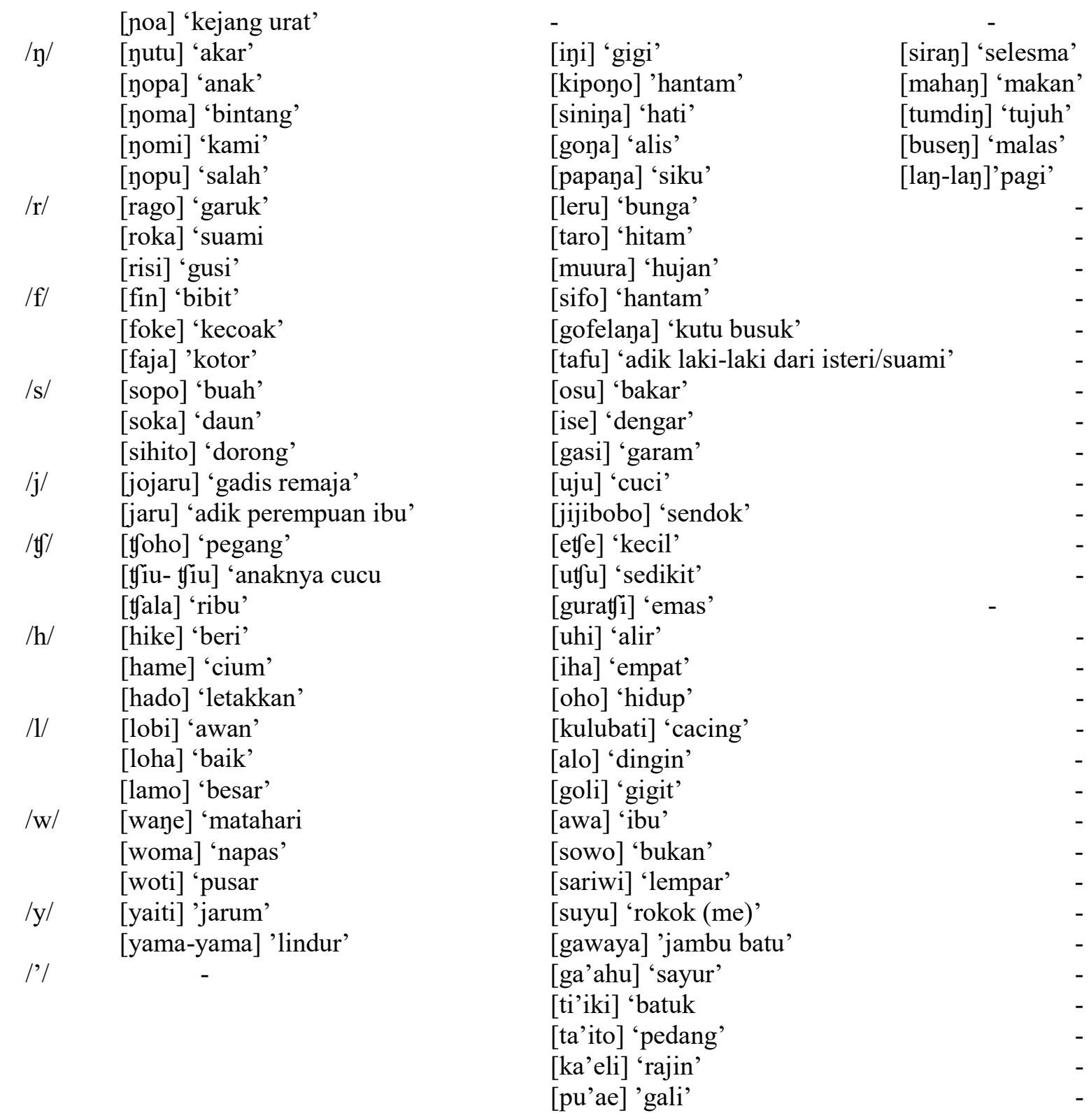

Pencarian fonem-fonem konsonan tersebut fonem-fonem konsonan isolek Morotai yang dilakukan dengan mencari pasangan minimal dikemukakan berikut ini.

\begin{tabular}{|c|c|c|c|c|}
\hline /dz/ & $/ \mathrm{d} /$ & [dzasi] 'telan' & : & [dasi] 'jabat tangan' \\
\hline & & [dziha] 'buru (ber)' & : & [diha] 'pisau' \\
\hline $\mathrm{t} /$ & $/ \mathrm{d} /$ & [tala] 'gunung' & : & [dala] 'banyak' \\
\hline & & [tudu] 'tikam' & & [dudu]' punggung' \\
\hline$/ \mathrm{t} /$ & /dg/ & [ete] 'kakek' & : & [edze] 'nenek' \\
\hline & & [tota] 'antar' & : & [dzota] 'jatuh' \\
\hline$/ \mathrm{k} /$ & $/ \mathrm{g} /$ & [kia] 'apa' & : & [gia] 'tangan' \\
\hline & & [oko] 'diri (ber)' & & [ogo] 'tenang \\
\hline$/ \mathrm{r} /$ & $/ 1 /$ & [ria] 'kakak' & : & [lia] 'tarik \\
\hline & & [rago] 'garuk' & & [lago] 'besar' \\
\hline$/ \mathrm{p} /$ & $/ \mathrm{b} /$ & [paro] 'angin' & : & [baro] 'kain' \\
\hline /f/ & $/ \mathrm{b} /$ & [faja] 'kotor' & : & [baja] 'bujuk \\
\hline$/ \mathrm{f} /$ & $/ \mathrm{p} /$ & [feto] 'kulum' & : & [peto] 'menyebutkan' \\
\hline$/ \mathrm{f} /$ & $\mid \mathrm{j} /$ & [ifa] 'papan' & : & [ija] 'beli \\
\hline$/ \mathrm{b} /$ & /w/ & [boro] 'telor' & 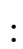 & [woro] 'luas' \\
\hline$/ \mathrm{p} /$ & $/ \mathrm{w} /$ & [palu] 'sahut (me)' & : & [walu] 'labu' \\
\hline
\end{tabular}




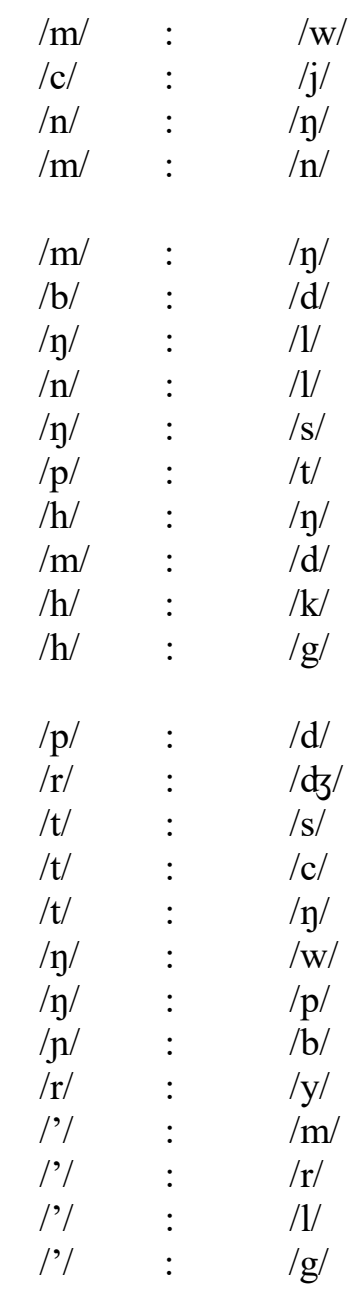

\subsubsection{Hal Lain tentang Bunyi Glottal}

Apabila terjadi afiksasi pada kosa-kata yang fonem pertamanya adalah vokal dan fonem akhir dari afiks-afiks tersebut adalah vokal, maka kita dapati ada glottal yang mengantarai antara afiks dan kosa kata itu sebagai penekanan pada kosa kata tersebut. Berikut ini adalah contoh-contohnya.

Tabel 4

Contoh ? Glottal

\begin{tabular}{|l|c|l|l|}
\hline $\begin{array}{l}\text { Kosa } \\
\text { kata }\end{array}$ & $\begin{array}{c}\text { Afi } \\
\text { ks }\end{array}$ & $\begin{array}{l}\text { Perubahan } \\
\text {-nya }\end{array}$ & $\begin{array}{l}\text { Contoh } \\
\text { dalam } \\
\text { kalimat }\end{array}$ \\
\hline [ake] 'air & da & $\begin{array}{l}\text { [da?ake] } \\
\text { 'berair' }\end{array}$ & $\begin{array}{l}\text { tamo } \\
\text { maga } \\
\text { yasakahi } \\
\text { da'ake } \\
\text { poli 'nasi } \\
\text { itu } \\
\text { dimasak } \\
\text { terlalu } \\
\text { berair' }\end{array}$ \\
\hline $\begin{array}{l}\text { [uhi] } \\
\text { 'bocor' }\end{array}$ & da & $\begin{array}{l}\text { [da?uhi]'ke } \\
\text { bocoran' }\end{array}$ & $\begin{array}{l}\text { maga } \\
\text { mago }\end{array}$ \\
\hline
\end{tabular}

[waro] 'lebur/lumer'

[uju] 'cuci'

[yau] 'telinga

[nano] 'melihat'

[nona]'engkau'

[yuna] 'muntah'

[doro] 'kebun'

[loha] 'baik'

[lako] 'mata'

[sone] 'mati'

[toko] 'ayam'

[nutu] 'akar'

[doi] 'pinggang'

[oko] 'diri (ber)'

[ogo] 'tenang'

[gogo] 'bulu'

[dola] 'naik'

[dzohe] 'tawa'

[side] 'layar'

[guraci] 'emas'

[yora] 'pintu'

[woma] 'napas'

[poosa] 'boros'

[boa] 'nanah'

[suyu] 'merokok'

[momane] 'kekasih'

[poroso] 'takut'

[poloso] 'genggam'

[togosa] 'gila'

\begin{tabular}{|c|c|c|c|}
\hline & & & $\begin{array}{l}\text { da'uhi ka } \\
\text { 'belanga } \\
\text { itu telah } \\
\text { kebocora } \\
\text { n' }\end{array}$ \\
\hline $\begin{array}{l}\text { [uku] } \\
\text { 'api' }\end{array}$ & da & $\begin{array}{l}\text { [daPuku] } \\
\text { terbakar' }\end{array}$ & $\begin{array}{l}\text { tahu } \\
\text { maga } \\
\text { da'uku } \\
\text { 'rumah } \\
\text { itu } \\
\text { terbakar' }\end{array}$ \\
\hline $\begin{array}{l}\text { [au] } \\
\text { 'darah' }\end{array}$ & $\mathrm{da}$ & $\begin{array}{l}\text { [da Pau] } \\
\text { 'berdarah, }\end{array}$ & $\begin{array}{l}\text { ai gia } \\
\text { da'au } \\
\text { 'tangank } \\
\text { u } \\
\text { berdarah } \\
\text {, }\end{array}$ \\
\hline $\begin{array}{l}\text { [oho]'hi } \\
\text { dup' }\end{array}$ & po & $\begin{array}{l}\text { [po?oho] } \\
\text { 'kita hidup' }\end{array}$ & $\begin{array}{l}\text { yone } \\
\text { mana } \\
\text { po'oho } \\
\text { gena } \\
\text { bilasu } \\
\text { pomakar } \\
\text { ajay 'kita } \\
\text { hidup }\end{array}$ \\
\hline
\end{tabular}




\begin{tabular}{|c|c|c|c|}
\hline & & & $\begin{array}{l}\text { harus } \\
\text { bekerja' }\end{array}$ \\
\hline $\begin{array}{l}\text { [eto] } \\
\text { 'hitung' }\end{array}$ & ya & $\begin{array}{l}\text { [yaPeto] } \\
\text { 'menghitun } \\
\text { g' }\end{array}$ & $\begin{array}{l}\text { nawa } \\
\text { imasisi'ij } \\
\text { a magena } \\
\text { mana } \\
\text { pipi } \\
\text { ya'eto } \\
\text { 'orang } \\
\text { yang } \\
\text { berjualan } \\
\text { itu } \\
\text { menghitu } \\
\text { ng } \\
\text { uangnya }\end{array}$ \\
\hline $\begin{array}{l}\text { [uri]'jahi } \\
\text { t' }\end{array}$ & na & $\begin{array}{l}\text { [naPuri]'(ka } \\
\text { mu) jahit' }\end{array}$ & $\begin{array}{l}\text { ani baju } \\
\text { na'uri } \\
\text { kasi, ai } \\
\text { raca ka } \\
\text { so } \\
\text { 'bajumu } \\
\text { itu } \\
\text { dijahit } \\
\text { dulu, } \\
\text { karena } \\
\text { telah } \\
\text { robek' }\end{array}$ \\
\hline $\begin{array}{l}\text { [ule] } \\
\text { 'main' }\end{array}$ & ou & $\begin{array}{l}\text { [ouPule] } \\
\text { '(dia) } \\
\text { bermain }\end{array}$ & $\begin{array}{l}\text { noudzoha } \\
\text { ka la } \\
\text { madudu } \\
\text { ka ou'ule } \\
\text { 'biarkan } \\
\text { saja dia } \\
\text { bemain } \\
\text { di luar }\end{array}$ \\
\hline $\begin{array}{l}\text { [odjo] } \\
\text { 'makan' }\end{array}$ & to & $\begin{array}{l}\text { [to?odzo] } \\
\text { '(saya) } \\
\text { makan' }\end{array}$ & $\begin{array}{l}\text { yohi } \\
\text { to'odzo } \\
\text { si 'saya } \\
\text { sedang } \\
\text { makan' }\end{array}$ \\
\hline $\begin{array}{l}\text { [udo] } \\
\text { 'minum' }\end{array}$ & $\mathrm{mo}$ & $\begin{array}{l}\text { [mo?udo] } \\
\text { '(dia) } \\
\text { minum' }\end{array}$ & $\begin{array}{l}\text { Tari teh } \\
\text { mo'udo } \\
\text { 'Tari } \\
\text { minum } \\
\text { teh' }\end{array}$ \\
\hline
\end{tabular}

\subsection{Proses Morfofonemik}

Menurut Ramlan (2001:83) bahwa morfofonemik mempelajari perubahanperubahan fonem yang timbul akibat pertemuan morfem dengan morfem lain. Selanjutnya, Ramlan (ibid) juga mengemukakan bahwa sedikitnya terdapat tiga proses morfofonemik dalam bahasa Indonesia, yaitu proses perubahan fonem, proses penambahan fonem, dan proses hilangnya fonem.

Adapun di dalam Enksilopedia Linguistik dijelaskan bahwa morfofonemik dalam pengertian yang paling luas adalah studi tentang struktur fonologi dari morfem misalnya kombinasi-kombinasi fonem-fonem yang dibolehkan di dalam morfem-morfem dalam setiap bahasa, termasuk variasi fonemik yang morfem-morfemnya mengalami kombinasi satu sama lain, dan studi tentang rangkaian pertukaran atau perubahan berulang di dalam fonem-fonem seperti perubahan dari fonem yang satu ke fonem yang lain (lihat: Malmkjaer, 1996:320). Demikian pula halnya dengan proses morfofonemik isolek Morotai, perubahan yang terjadi karena proses afiksasi seperti berikut ini.

1. Jika $N$ - muncul pada akar kata yang huruf awalnya adalah vokal /a/, /i/,/u/,/e/,/o/, Nberubah menjadi /g/ seperti pada contoh berikut.

$\begin{array}{ll}N-\rightarrow \quad & \text { ari 'menangis' } \\ \text { gari 'menangisi/tangisan' } & \rightarrow \\ & \text { ise 'dengar' } \\ & \text { gise 'mendengar' } \\ & \text { uri 'jahit (transitif)' } \rightarrow \\ & \text { guri 'jahit (intransitif)' } \\ & \text { eto 'hitung' } \\ & \text { geto 'menghitung' } \\ & \text { oko 'diri (ber)' } \\ & \text { goko'berdiri' }\end{array}$

2. Jika $N$ - muncul pada kata $u$ hi 'alir' yang huruf awalnya adalah /u/, $N$ - akan berubah menjadi /yu/, sehingga kata tersebut menjadi $\eta u$ Puhi 'banjir'

3. Jika $N$ - muncul pada akar kata yang huruf awalnya adalah /p/, $N$ - berubah menjadi /b/ seperti contoh berikut ini. $N-\rightarrow$

$$
\begin{aligned}
& \text { puPae 'gali' } \rightarrow \\
& \text { bu?ae 'menggali' } \\
& \text { piliku 'ikat' } \rightarrow \\
& \text { biliku 'ikatan' }
\end{aligned}
$$




putu 'malam' $\rightarrow$
butu 'malam'
pereki 'tua' $\rightarrow$
bereki 'orang yang sudah
tua'
po?osa 'boros' $\rightarrow$
bo?osa 'pemborosan

4. Jika $N$ - muncul pada akar kata yang huruf awalnya adalah /t/, $N$ - akan berubah menjadi /d/ seperti contoh berikut ini

$\begin{aligned} N-\rightarrow \quad & \text { temo 'kata (ber)' } \rightarrow \\ & \text { demo 'perkataan' } \\ & \text { tagi 'berjalan' } \rightarrow \\ & \text { dagi 'perjalanan' } \\ & \text { torou 'buruk' } \rightarrow \\ & \text { dorou 'keburukan' } \\ & \text { tebi 'bersih' } \rightarrow \\ & \text { debi 'membersihkan } \\ & \text { (sesuatu)' }\end{aligned}$

5. Jika $N$ - muncul pada akar kata yang huruf awalnya adalah $/ \mathrm{k} /, N$ - akan berubah menjadi /g/ seperti contoh berikut ini.
$N-\rightarrow$
kiolo 'tidur' $\rightarrow$
giolo 'tidur'
kurati 'kuning' $\rightarrow$
gurati 'kunyit'
kaku 'tinggi' $\rightarrow$
gaku 'ketinggian'
kiPopi 'asam $\rightarrow$
gi?opi 'keasaman'

6. Jika $N$ - muncul pada akar kata yang huruf awalnya adalah $/ \mathrm{h} /, N$ - akan berubah menjadi $/ \mathrm{y} /$ dan $/ \mathrm{n} /$ seperti contoh berikut ini.

$\mathrm{N}-\rightarrow \quad$ hado 'meletakkan (sesuatu di suatu tempat yang bukan sebuah wadah tertentu)'

yado 'meletakkan/menaruh (makanan/suatu benda pada suatu wadah tertentu)'

hoi 'buka' $\rightarrow$ yoi

\section{hagi 'berhutang' $\rightarrow$ \\ nagi 'hutang'}

7. Jika $N$ - muncul pada akar kata yang huruf awalnya /dz/, maka $N$ - akan berubah menjadi /n/ seperti contoh berikut ini.

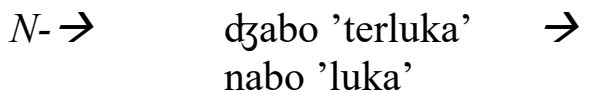

8. Jika $N$ - muncul pada kata wosa 'masuk' yang huruf awalnya adalah $/ \mathrm{w} /, \mathrm{N}$ - akan berubah menjadi /y/ sehingga kata tersebut menjadi yosa 'masuk'.

9. Jika daN- muncul bersama akar kata yang huruf awalnya adalah vokal /a/, /i/, /u/, /e/, /o/, $N$ - akan berubah menjadi glottal stop /P/ seperti pada contoh berikut.

$d a N-\rightarrow$

$$
\begin{aligned}
& \text { ake 'air' } \\
& \text { daPake 'berair' } \\
& \begin{array}{l}
\text { uku 'api' } \\
\text { daPuku 'terbakar' }
\end{array} \\
& \begin{array}{l}
\text { ece 'kecil' } \\
\text { daPece 'kekecilan' }
\end{array} \\
& \begin{array}{l}
\text { ohu 'mentah' } \rightarrow \\
\text { daPohu 'itu mentah' }
\end{array}
\end{aligned}
$$

10. Jika $d o N-$ mncul bersama akar kata yang huruf awalnya konsonan /1/,/s/,/t/, Nakan berubah menjadi zero $/ \mathrm{O} /$ seperti pada contoh berkut ini.

$\begin{aligned} d o N-\rightarrow \quad \begin{array}{l}\text { lodza 'lari' } \\ \text { dolodza } \\ \text { 'tinggalkan }\end{array} & \rightarrow \\ & \text { sora 'menyala' } \rightarrow \\ & \text { dosora } \\ & \text { 'menyalakan' }\end{aligned}$

11. Jika $d u N$ - muncul pada akar kata atau bentuk dasar yang huruf awalnya konsonan /t/, /g/, $N$ - akan berubah menjadi zero /O/ eperti contoh berikut. $\begin{array}{ll}d u N-\rightarrow \quad \begin{array}{l}\text { turaba 'hancur' } \\ \text { doturaba 'tura } \\ \text { dutura 'kejatuhan' }\end{array} & \rightarrow \text { 'jatuh'; }\end{array}$ 


$$
\begin{aligned}
& \text { tupu 'bakar' } \\
& \text { dutupu 'terbakar' }
\end{aligned} \rightarrow
$$

12. Jika siN-muncul bersama akar kata yang huruf awalnya adalah vokal /a/, /i/, /u/, /e/, /o/, $N$ - akan berubah menjadi glottal stop / $/$ / seperti pada contoh berikut ini.

$$
\begin{aligned}
& \text { siN }-\rightarrow \text { uhi 'alir' } \rightarrow \\
& \text { si?uhi 'alirkan' } \\
& \text { ihe 'tertawa' } \rightarrow \\
& \text { si?ihe 'tertawakan' } \\
& \text { odzo 'makan' } \rightarrow \\
& \text { si?odzo 'makan dengan } \\
& \text { sesuatu' } \\
& \text { ese ' gosok' } \rightarrow \\
& \text { si?ese 'gosokkan' } \\
& \text { uku 'api' } \rightarrow \\
& \text { si?uku 'hanguskan' }
\end{aligned}
$$

13. Jika siN- muncul bersama akar kata atau bentuk dasar yang huruf awalnya konsonan, $N$ - berubaha menjadi zero /O/ seperti pada contoh berikut ini.

$$
\begin{aligned}
& \text { siN } \rightarrow \text { lodza 'lari' } \rightarrow \\
& \text { silodza 'larikan' } \\
& \text { piliku 'ikat' } \rightarrow \\
& \text { sipiliku 'ikatkan' } \\
& \text { nuna 'muntah' } \rightarrow \\
& \text { sinuna 'muntahkan' } \\
& \text { guri 'menjahit' } \rightarrow \\
& \text { siguri 'menjahitkan' } \\
& \text { goko 'berdiri' } \rightarrow \\
& \text { sigoko 'mendirikan' }
\end{aligned}
$$

\begin{tabular}{|c|c|}
\hline$k o N-\rightarrow$ & $\begin{array}{l}\text { pola 'tumpah' } \\
\text { kopola 'tertumpah }\end{array}$ \\
\hline & $\begin{array}{l}\text { sike 'kentut' } \\
\text { kosike 'mengentut }\end{array}$ \\
\hline & $\begin{array}{l}\text { doto 'didik' } \\
\text { kodoto' }\end{array}$ \\
\hline & $\begin{array}{l}\text { toti 'gendong' } \\
\text { kototi' }\end{array}$ \\
\hline
\end{tabular}

14. Jika $k o N$ - muncul bersama akar kata yang huruf awalnya adalah vokal, $\mathrm{N}$ akan berubah menjadi glottal stop /'/ seperti pada contoh berikut ini.

$$
k o N-\rightarrow \quad \begin{aligned}
& \text { ora 'rebut' } \\
& \text { ko'ora 'berebut' }
\end{aligned} \rightarrow
$$

15. Jika kiN- muncul bersama akar kata yang huruf awalnya konsonan /t/, $\mathrm{N}$ - berubah menjadi /O/ seperti pada contoh berikut ini.

$$
\begin{array}{ll}
k i N-\rightarrow \quad & \text { toka 'setan' } \rightarrow \\
\text { kitoka 'menjadi setan' } \\
\text { tide 'angkat' } \rightarrow \\
\text { kitide 'angkat (bersama- } \\
\text { sama)' }
\end{array}
$$

16. Jika $k u N-$ muncul bersama akar kata yang huruf awalnya konsonan /d/, Nberubaha menjadi $/ \mathrm{O} /$ seperti pada contoh berikut ini.

$$
k u N-\rightarrow \quad \begin{aligned}
& \text { dubu 'tinju' } \\
& \text { kudubu 'bertinju' }
\end{aligned} \rightarrow
$$

17. Jika $k o N$ - muncul bersama akar kata yang huruf awalnya konsonan /p/, /s/, /d/, /t/, $N$ - berubah menjadi /O/ seperti pada contoh berikut ini.

18. Jika $k e N$ - muncul bersama akar kata yang huruf awalnya konsonan /r/, $N$ - berubah menjadi /O/ seperti pada contoh berikut ini.

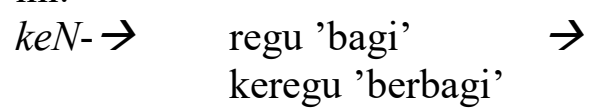

19. Jika toN muncul bersama akar kata yang huruf awalnya vokal, $\mathrm{N}$ - berubah menjadi glottal /'/ seperti pada contoh berikut ini.

$$
\begin{aligned}
& \text { toN- } \rightarrow \text { ore 'teriak' } \rightarrow \\
& \text { to?ore 'berteriak' }
\end{aligned}
$$

20. Jika teN- muncul bersama akar kata yang huruf awalnya konsonan, N- berubah menjadi /O/ seperti pada contoh berikut ini

teN- $\rightarrow$ mehe 'lambat' $\rightarrow$ temehe 'yang lambat' 
21. Jika taN- muncul bersama akar kata atau bentuk dasar yang huruf awalnya konsonan, $\mathrm{N}$ - berubah menjadi /O/ seperti pada contoh berikut ini.

$$
\begin{aligned}
\text { taN- } \rightarrow \quad \begin{array}{l}
\text { madze 'malu' } \\
\text { tamadze 'pemalu' }
\end{array} & \rightarrow \\
& \text { gari 'tangisan' } \rightarrow \\
& \text { tagari 'cengeng' }
\end{aligned}
$$

22. Jika tiN- muncul bersama akar kata yang huruf awalnya konsonan, N- berubah menjadi /O/ dan jika tiN- muncul bersama akar kata yang huruf awalnya vokal, berubah menjadi glottal //, seperti pada contoh berikut ini.

$\begin{array}{lll}\text { tiN- } \rightarrow & \text { gira } & \rightarrow \\ \text { tigira } & \\ & \text { aru } & \rightarrow\end{array}$

23. Jika riN- muncul bersama akar kata yang huruf awalnya konsonan, N- berubah menjadi /O/ seperti pada contoh berikut ini.

$$
\begin{array}{ll}
\text { riN- } \rightarrow \quad \begin{array}{l}
\text { napo 'pukul' } \\
\text { rinapo 'saling } \\
\text { memukul' }
\end{array} & \rightarrow \\
\begin{array}{l}
\text { holu 'tidak mau' } \\
\text { riholu 'bercerai' }
\end{array} & \rightarrow \\
\text { dzehe 'ambil' } \\
\text { ridehe 'rujuk' }
\end{array} \rightarrow
$$

24. Jika giN- muncul bersama akar kata yang huruf awalnya konsonan, N- berubah menjadi /O/ dan akan berubah menjadi glottal /// jika muncul bersama akar kata yang huruf awalnya vokal seperti pada contoh berikut ini.

$$
\begin{aligned}
& \text { giN- } \rightarrow \text { nano 'lihat' } \rightarrow \\
& \text { ginano 'melihat' } \\
& \text { ihu 'simpan' } \rightarrow \\
& \text { gi'ihu 'menyimpan' }
\end{aligned}
$$

25. Jika biN- muncul bersama akar kata yang huruf awalnya konsonan, N- berubah menjadi /t/ pada kata ogu dan akan berubah menjadi/O/ pada kata yang lain seperti pada contoh berikut ini.

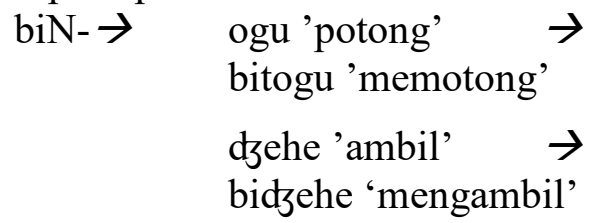

26. Jika afiks-afiks kata ganti orang seperti to-, no-, yo-, wo-, mo-, po-, mi-,ni-, ta-, na-, ya-, wa-, ma-, pa- muncul bersama akar kata atau bentuk dasar yang huruf awalnya konsonan, N- akan berubah menjadi /O/, dan apabila muncul bersama akar kata yang huruf awalnya vokal, Nakan berubah menjadi glottal, seperti pada contoh berikut ini.

$$
\begin{array}{ll}
\text { to- } \rightarrow \quad \text { tagi 'pergi' } \\
\\
\text { yohi totagi 'saya } \\
\text { pergi' }
\end{array}
$$

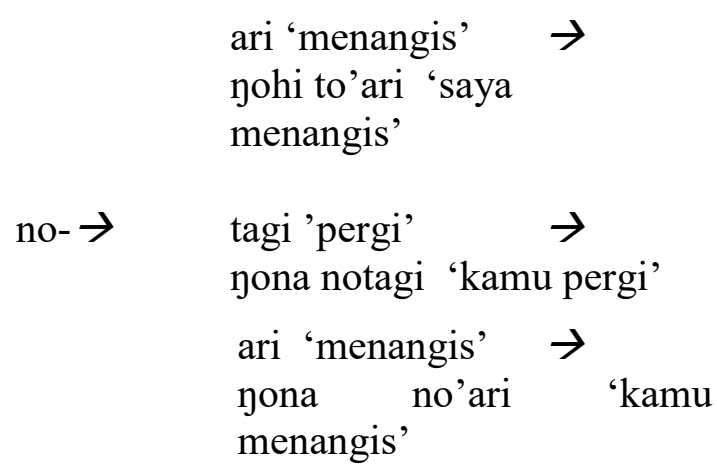

\section{Simpulan}

Berdasarkan paparan dan analisis data tentang isolek non-Austronesia di Pulau Morotai disumpulkan bahwa pencarian fonem melalui minimal pair ditemukan sebagai berikut.

1. Isolek Morotai mempunyai lima fonem vokal: /a/, /e/, /i/, /o/, /u/ yang terdistrubusi secara merata di awal, tengah, dan akhir kata dalam isolek Morotai.

2. Isolek Morotai mempunyai 15 bunyi diftong, yaitu /ia/, /ao/, /uo/, /ou/, /eo/, /ae/, /oi/, /au/, /io/, /oa/, /ue/, /iu/, /ai/, /ui/, /ua/, dan terdpat 10 bunyi diftong yang distrbusinya hanya ditemukan pada akhir kata, yaitu /ao/, /uo/, /ou/, /eo/, /ae/, /oi/, /io/, /oa/, /iu/, /ui/. 
3. Isolek Morotai mempunyai 21 fonem konsonan: /p/,/t/, /k/, /P/, /b/, /dz/,/d/,/g/, $/ \mathrm{m} /, / \mathrm{n} /, / \mathrm{n} /, / \mathrm{y} /, / \mathrm{r} /, / \mathrm{f} /, / \mathrm{s} /, / \mathrm{j} /, / \mathrm{h} /, / \mathrm{g} /, / \mathrm{l} /$, $/ \mathrm{w} /, / \mathrm{y} /$, dari 21 fonem tersebut hanya ada tiga fonem yang ditemukan distribusinya pada akhir kata, yaitu /m/, /n/, /y/.

4. Proses morfofonemik pada isolek Morotai terjadi karena adanya proses afiksasi.

5. Apabila terjadi afiksasi pada kosa-kata yang fonem pertamanya vokal dan fonem akhir dari afiks-afiks tersebut adalah vokal juga, maka muncul bunyi glottal yang mengantarai antara afiks dan kosa kata itu sebagai penekanan pada kosa kata tersebut.

6. Secara kuantitatif ditemukan pula 26 keadaan lainnya yang menyebabkan terjadinya proses morfofonemik pada isolek Morotai.

\section{Daftar Pustaka}

Kridalaksana, Harimurti. 2001. Kamus Linguistik, Edisi Ketiga. Jakarta Gramedia Pustaka Utama.

Kridalaksana, Harimurti. 2005. Leksikon, dalam Kushartanti; Untung Yuwono; Multamia RMT Lauder, Pesona Bahasa Langkah Awal Memahami Linguistik. Jakarta: Gramedia Pustaka Utama.
Ladefoged, Peter. 1982. A Course in Phonetics. Second Edition. United States of America: Harcourt Brace Jovanovich, Inc.

Mahsun. 1995. Dialektologi Diakronis Sebuah Pengantar. Yogyakarta: Gadjah Mada University Press.

Mahsun. 2005. Metode Penelitian BahasaTahapan Strategi, Metode, dan Tekniknya. Jakarta: PT. RajaGrafindo Persada

Malmkjaer, Kirsten , editor. 1996. The Linguistics Encyclopedia. London and New York: Routledge

Moeimam, Susi \& Hein Steinhauer. 2005. Kamus Belanda-Indonesia. Jakarata: KITLV dan PT Gramedia Pustaka Utama.

Ramlan, M. 2001. Morfologi Suatu Tinjauan Deskriptif. Yogyakarta: C. V. Karyono.

Verhaar, J. W. M. 2004. Asas-Asas Linguistik Umum. Yogyakarta: Gadjah Mada University Press.

Wahya, 2011. Fenomena Difusi Leksikal Unsur Bahasa. Jurnal Sosioteknologi, edisi 23 Tahun 10, Agustus 2011. Hal $1110-1116$

Wilkinson, R. J. tt. Malay- English Dictionary (Romanised). Tokyo: Daitoa Syuppan Kabusiki Kaisya. 